\title{
ANALISIS LEBAR SELASAR PEJALAN KAKI PADA PASAR ANTASARI KOTA BANJARMASIN
}

\author{
Hudan Rahmani \\ Staf Pengajar Jurusan Teknik Sipil \\ Universitas Islam Kalimantan MAB Banjarmasin \\ E-mail: hudanrahmani1310@gmail.com/HP. 0812-502-4488
}

\begin{abstract}
ABSTRAK
Pejalan kaki merupakan salah satu bentuk lalu lintas dalam sistem transportasi, dan sangat dominan di daerah perkotaan, Central District Business (CBD) atau lokasi yang memiliki permintaan tinggi dengan periode pendek contohnya di Pusat Perbelanjaan. Lebar efektif adalah salah satu faktor utama dalam perancangan, perencanaan, maupun pengoperasian fasilitas-fasilitas transportasi. Hasil studi ini diharapkan dapat digunakan sebagai salah satu bahan acuan dalam kaitannya dengan fasilitas-fasilitas transportasi di Indonesia, mengingat belum adanya pembahasan mengenai hal ini pada Manual Kapasitas Jalan Indonesia (MKJI), sedangkan hal ini sudah dibahas dan baru ada di Highway Capacity Manual (HCM-1985) dari Amerika. Pengambilan data dilakukan dengan menggunakan alat kamera video, pada waktu kondisi arus puncak dan arus normal, di lokasi Selasar pada Pasar Antasari untuk mengetahui Lebar Efektif Selasar berdasarkan konsep Level of Service (LOS) dari HCM (1985) dari Amerika. Dari hasil perhitungan didapatkan Lebar Efektif Selasar pada waktu puncak menjelang lebaran Idul Fitri sebesar 0,594 m dengan ruang 1,69 $\mathrm{m}^{2} /$ ped dan untuk waktu normal setelah lebaran Idul Fitri sebesar 1,08 $\mathrm{m}$ dengan ruang $3,063 \mathrm{~m}^{2} /$ ped.
\end{abstract}

Kata kunci: Arus pejalan kaki, selasar lurus, kecepatan, kerapatan atau ruang, lebar efektif.

\begin{abstract}
Pedestrians is one form of traffic hi the transport system, and very dominant in urban areas, Central Business District (CBD) or a location that has a high demand in the short period for example in Shopping Center. Effective width is one of the key factors in the design, planning, and operation of transportation facilities. Results of this study are expected to be used as one of the reference materials in relation to transportation facilities in Indonesia, given the absence of discussion about this on Manual Kapasitas Jalan Indonesia (MKJI), whereas it has been discussed and new exist in Highway Capacity Manual (HCM-1985) from America. Data were collected by using a video camera, at the time of peak current and the current conditions of normal, at a location on Market Selasar Antasari to determine the Effective Width breezeway based on the concept of Level of Service (LOS) of HCM (1985) from America. From the results of the calculation, Effective Width breezeway at peak times before Idul Fitri of $0.594 \mathrm{~m}$ with a time of 1.69 $\mathrm{m}^{2} / \mathrm{ped}$ and to normal after Idul Fitri at $1.08 \mathrm{~m}$ with a 3,063 $\mathrm{m}^{2} / \mathrm{ped}$.

Keywords: Pedestrian flow, Straight hallway, Acceleration, Density or space, the Effective width.
\end{abstract}




\section{PENDAHULUAN}

\section{Latar Belakang}

Pejalan kaki salah satu bentuk dari sistem transportasi. Kehadiran pejalan kaki yang sangat dominan di daerah perkotaan dan Central Business District (CBD) akan menimbulkan masalah baik untuk lalu lintas kendaraan maupun bagi sesama pejalan kaki itu sendiri. Fasilitas pejalan kaki dibutuhkan sekali antara lain pada lokasi-lokasi yang memiliki kebutuhan/permintaan tinggi dengan periode pendek, seperti pusat perkotaan, CBD, terminal induk dan lain-lain. Di Indonesia telah ada Indonesia Highway Capacity Manual (IHCM) atau sering di sebut dengan Manual Kapasitas Jalan Indonesia (MKJI). MKJI hanya membahas khusus masalah lalu lintas kendaraan sedangkan lalu lintas pejalan kaki belum dibahas sama sekali. Sehingga untuk mengadakan perancangan, perencanaan dan analisa operasional khusus pejalan kaki di Indonesia dapat menggunakan acuan atau manual dari negara lain khususnya dari Amerika maupun Eropa. Pasar Antasari merupakan pasar yang cukup besar dengan luas \pm 4 hektar mempunyai ciri khas yaitu moda transportasi yang menuju tempat ini bisa melewati 2 jalur yaitu melewati jalan raya dan juga bisa lewat Sungai Martapura. Di Pasar Antasari ada 2 sub terminal kota (Angkot) dan 2 sub dermaga kapal kecil yang disebut kelotok Para pembeli yang datang di pasar ini tidak hanya dari wilayah Kalimantan Selatan saja tetapi juga bisa berasal dari Kalimantan Tengah dan Timur. Fasilitas yang ada untuk pejalan kaki pada Pasar Antasari tersebut berupa selasar. Unsur yang menimbulkan bangkitan pejalan kaki di pasar ini adalah:

1. Orang yang berbelanja dengan menggunakan kendaraan pribadi dan kendaraan umum baik lewat darat maupun lewat sungai menuju Pasar Antasari.

2. Orang yang bekerja sebagai pedagang maupun karyawan pada toko-toko dan perusahaan-perusahaan yang berada di kompleks pasar ini.

Dengan kondisi ini di atas maka pejalan kaki di Pasar Antasari cukup kompleks apalagi pada saat mendekati hari besar seperti Idul Fitri. Pemerintah Indonesia dalam melindungi para pejalan kaki (pedestrian) tertera dalam UU nomor 14 tahun 1992 serta PP nomor 43 tahun 1993 pasal 39, mencantumkan beberapa butir fasilitas pejalan kaki terdiri dari a) Trotoar atau selasar b) Tempat penyeberang yang dinyatakan dengan marka jalan atau zebra cross c) Jembatan penyeberangan dan d) Terowongan penyeberang.

\section{Perumusan Masalah}

Perumusan masalah dari penelitian ini adalah:

Berapakah lebar efektif selasar yang didasarkan dari level of service dari konsep HCM (1994).

\section{Tujuan Penelitian}

Adapun tujuan yang diharapkan dapat diperoleh dalam studi ini adalah sebagai berikut:

Untuk mengetahui lebar efektif selasar yang didasarkan dari level of service dari konsep HCM (1994). 


\section{Batasan Masalah}

Adanya keterbatasan yang dimiliki oleh peneliti maka peneliti merasa perlu membatasi permasalahan ini yang dirasa begitu kompleks dalam penelitian ini yaitu:

1. Lokasi penelitian hanya pada selasar lurus Pasar Antasari yaitu pada tempattempat pejalan kaki yang berupa selasar jalan.

2. Waktu penelitian diambil pada saat dalam keadaan sibuk, normal dan pada saat pasar sibuk menjelang hari raya Idul Fitri.

\section{Manfaat Penelitian}

Adapun manfaat penelitian ini adalah:

Untuk meningkatkan kinerja fasilitas yang sudah ada sebagai perbaikan dari fasilitas yang sudah dilaksanakan.

\section{TINJAUAN PUSTAKA}

\section{Umum}

Fasilitas pejalan kaki dalam khasanah transportasi dapat berupa trotoar, jalan khusus pejalan kaki yang sebidang maupun tidak sebidang. Dengan adanya fasilitas pejalan kaki diharapkan dapat meningkatkan keamanan, kenyamanan maupun kecepatan waktu atau beijalan. Hal ini senada dengan pendapat dari Oghigian (1974:273) sebagai berikut:

1. Menyediakan fasilitas pejalan kaki yang dapat meningkatkan fungsi kesinambungan, keselamatan lingkungan bagi pejalan kaki.

2. Menyediakan fasilitas pejalan kaki yang tidak berbahaya bagi keselamatan para pejalan kaki.

3. Meningkatkan kenyamanan bagi para pejalan kaki, yang meliputi kemudahan dan keamanan bagi pejalan kaki.

Lalu lintas pejalan kaki di trotoar maupun di jalur khusus pejalan kaki sangat mempengaruhi oleh adanya hambatan-hambatan dan pengurangan area, berhenti dan adanya perabotan-perabotan jalan misalnya tiang, tempat sampah, orang berjualan, tempat telpon begitu juga berupa kotak surat dan lain sebagainya.

\section{Terminologi Kapasitas Pejalan Kaki}

Dalam menganalisa pejalan kaki terdapat beberapa istilah-istilah seperti hal analisa untuk lalu lintas lainnya, istilah-istilah dan definisi yang sering dan umum digunakan menurut Highway Capacity Manual (1994:13-3) dari Amerika antara lain adalah:

1. Kecepatan pejalan kaki: rata-rata kecepatan pejalan kaki (m/mnt)

2. Arus pejalan kaki: jumlah pejalan kaki yang melewati suatu titik persatuan waktu (ped/mnt)

3. Aliran per satuan lebar: rata-rata jumlah pejalan kaki dalam per satuan lebar efektif lajur pejalan kaki (ped/mnt/m)

4. Kerapatan pejalan kaki: rata-rata jumlah pejalan kaki dalam suatu satuan luas di dalam lajur pejalan kaki (ped $\left./ \mathrm{m}^{2}\right)$

5. Ruangan pejalan kaki: rata-rata luas yang tersedia untuk setiap pejalan kaki pada lajur pejalan kaki ( $\mathrm{m}^{2} /$ ped) 


\section{Prinsip Dasar Waktu dan Ruang}

\section{Penentuan Total Waktu-Ruang}

Total waktu yang tersedia yang diperlukan untuk pejalan kaki untuk beijalan di luas lajur (selasar). Sebagai dasar perhitungan menurut HCM (1994:13-22) dari Amerika adalah:

$\mathrm{A}=\mathrm{W} \times \mathrm{L}-\left(\mathrm{C}_{\mathrm{tot}}\right)$

$\mathrm{TS}=\mathrm{A} \times \mathrm{i}$

Keterangan:
$\mathrm{A}=$ Luas Efektif segmen / selasar $\left(\mathrm{m}^{2}\right)$
$\mathrm{W}=$ Lebar segmen / selasar $(\mathrm{m})$
$\mathrm{C}_{\text {tot }}=$ Luas halangan tetap / tidak tetap $\left(\mathrm{m}^{2}\right)$
$\mathrm{L} \quad=$ Panjang segmen $(\mathrm{m})$
$\mathrm{TS}=$ Total waktu ruang ditetapkan selama satu satuan $\left(\mathrm{m}^{2}-\right.$ menit $)$
I = Interval waktu pengamatan (menit)

\section{Penentuan Waktu Berjalan Rata-rata}

Waktu yang dibutuhkan rata-rata pejalan kaki menempati segmen lajur khusus pejalan kaki, didapat dengan perhitungan sebagai berikut:

$\mathrm{Tw}=(\mathrm{N} 1 \times \mathrm{t} 1+\mathrm{N} 2 \times \mathrm{t} 2+\ldots .+\mathrm{Nn} \times \mathrm{tn}) /(\mathrm{N} 1+\mathrm{N} 2+\ldots+\mathrm{Nn})$

Keterangan:

$\mathrm{Tw}=$ Waktu pejalan kaki yang sedang berjalan (dtk)

$\mathrm{N} \quad=$ Jumlah pejalan kaki yang sedang berjalan di segmen pengamatan

$\mathrm{T} \quad=$ Waktu yang digunakan pejalan kaki di segmen pengamatan

\section{Menentukan Kecepatan Rata-rata}

Kecepatan rata-rata seorang pejalan kaki berjalan pada segmen pengamatan dengan rumus dibawah ini:

Speed $=\mathrm{L} / \mathrm{tw}$

Keterangan:

Speed $=$ Kecepatan rata-rata pejalan kaki seorang pejalan kaki $(\mathrm{m} / \mathrm{mnt})$

$\mathrm{L} \quad=$ Panjang segmen pengaman $(\mathrm{m})$

$\mathrm{Tw}=$ Waktu rata-rata yang dibutuhkan seorang pejalan kaki di segmen lajur pengamatan (dtk)

\section{Menentukan Waktu Total Menempati Lokasi Pengamatan}

Waktu total pejalan kaki menempati lokasi pengamatan adalah hasil dari waktu rata-rata berjalan dan jumlah pejalan kaki yang menggunakan segmen lajur pengamatan selama dalam satuan waktu tertentu sesuai dengan rumus HCM (1994) sebagai berikut:

$\mathrm{Tw}=\mathrm{V} \times \mathrm{tw} / 60$

$\mathrm{V}=$ Volume pejalan kaki diamati dalam segmen lajur pengamatan (ped/mnt)

$\mathrm{Tw}=$ Waktu rata-rata yang dibutuhkan seorang pejalan kaki di segmen lajur pengamatan $(\mathrm{dtk})$ 


\section{Menentukan Ruang Rata-rata per Pejalan Kaki dan Tingkat Pelayanan Rata-rata}

Merupakan hasil rata-rata area yang disediakan untuk setiap pejalan kaki

$\mathrm{M}=\mathrm{TS} / \mathrm{Tw}$

Keterangan:

$\mathrm{M} \quad=$ Ruang rata-rata pejalan $\mathrm{kaki}\left(\mathrm{m}^{2} / \mathrm{ped}\right)$

TS = Waktu ruang total yang tersedia di segmen lajur pengamatan selama satuan waktu tertentu $\left(\mathrm{m}^{2}\right.$-mnt)

$\mathrm{Tw}=$ Waktu total penempatan di lajur pengamatan (ped-mnt)

\section{Menentukan Kerapatan Rata-rata Pejalan kaki}

Ditentukan sebagai fungsi kebalikan dan ruang sirkulasi rata-rata per pejalan kaki.

Kerapatan $=$ Kebalikan dari ruang

$\mathrm{K} \quad=1 / \mathrm{M}$

Keterangan:

$\mathrm{K}=$ Kerapatan rata-rata pejalan kaki di selasar/segmen pengamatan lajur khusus pejalan kaki (ped/nr)

$\mathrm{M}=$ Ruang rata-rata per pejalan kaki $\left(\mathrm{m}^{2} / \mathrm{ped}\right)$

\section{Lebar Efektif Lajur Khusus Pejalan Kaki}

Menurut HCM (1994:13-14), mengenai “Lebar Laju Efektif Pejalan Kaki” adalah berhubungan langsung dengan lebar selasar yang dapat digunakan secara efektif oleh pejalan kaki. Gerakan pejalan kaki akan menjauhi batas dan tidak akan merapat/mendeteksi terlalu dekat dengan dinding bangunan. Oleh karena itu, ruangan yang tidak digunakan harus dikurangi saat menentukan Tingkat Pelayanan (LOS) pejalan kaki. Dan selanjutnya jarak yang ditempati oleh pejalan kaki seperti melihat-lihat etalase dan terdapat halangan fisik seperti tiang, kotak surat, tempat telpon dan indikator lainnya yang harus diperhitungkan. Halangan tersebut diatas akan mempengaruhi gerakan pejalan kaki serta mengurangi lebar atau area tempat pejalan kaki.

\section{METODE PENELITIAN}

\section{Program Kerja Penelitian}

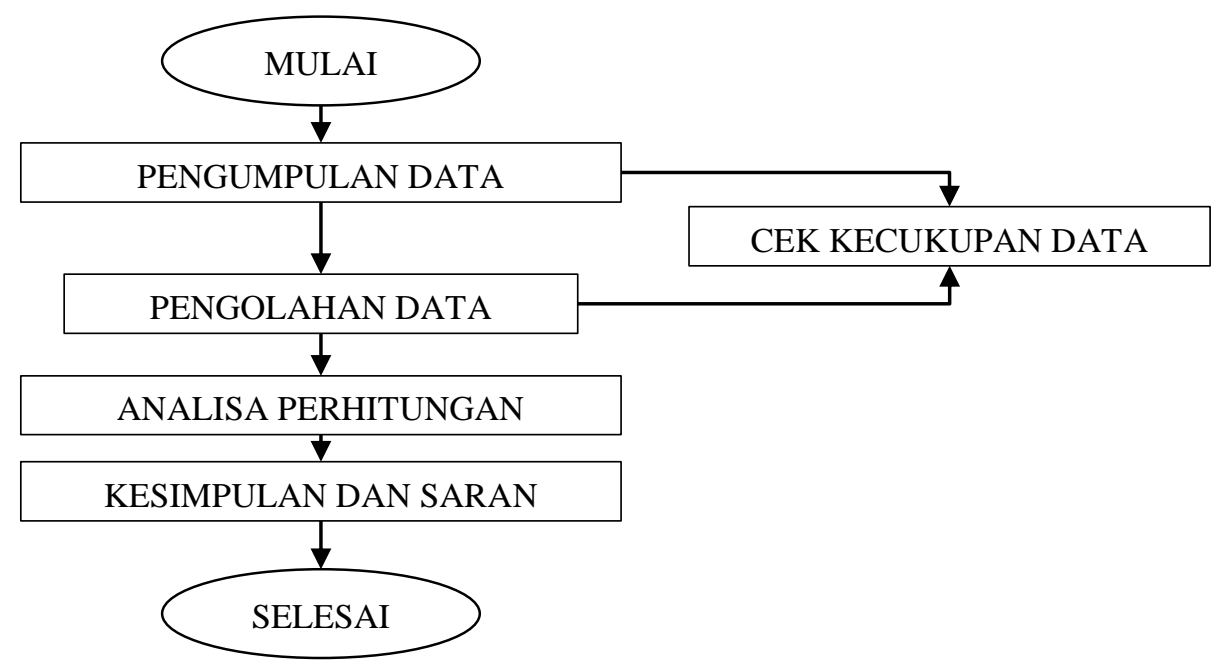




\section{Pengumpulan Data}

Pengumpulan data dilaksanakan pada waktu atau jam-jam tertentu dan juga pada hari-hari tertentu pula dengan maksud untuk mendapatkan kondisi arus padat atau disebut Waktu Puncak (peak times) dan kondisi Arus biasa atau disebut Waktu normal (normal times). Dalam penelitian ini waktu puncak diambil pada saat 5-1 menjelang lebaran Idul Fitri, pengambilan data pada hari Senin tanggal 03 Juni 2019 pada pukul 11.30 - 12.00 WITA. Pengambilan data pada kondisi arus biasa atau waktu normal dilakukan pada hari Rabu tanggal 26 Juni 2019 pada pukul 11.30 - 12.00 WITA.

\section{Pemilihan Lokasi Dan Waktu Pemilihan Lokasi}

1. Selasar lurus pejalan kaki yang mempunyai lebar cukup

2. Terdapat fluktuasi arus pejalan kaki seperti arus puncak dan arus normal

3. Selasar lurus khusus pejalan kaki

4. Selasar lurus pejalan kaki yang tidak mempunyai kemiringan medan.

5. Selasar lurus pejalan kaki yang lurus dan tidak berbelok-belok.

6. Jalur yang sering dilewati oleh pejalan kaki atau dianggap strategis bagi pejalan kaki.

7. Dapat dengan mudah untuk penempatan peralatan pengamatan.

Berdasarkan dari kriteria tersebut diatas. maka lokasi pengamatan yang paling tepat adalah pada lokasi selasar lurus pejalan kaki di Pasar Antasari dari ujung Terminal Antasari Barat pojok masjid Pasar Antasari.

\section{Pemilihan Waktu}

Dalam menentukan waktu pelaksanaan pengamatan atau pengumpulan data dilakukan pada pukul $\pm 08.30- \pm 15.30$ WITA pada waktu/kondisi normal dan pada waktu/kondisi sibuk ditentukan pada hari-hari menjelang lebaran Idul Fitri, sedangkan waktu/kondisi normal ditentukan pada hari-hari biasa, rekaman video 8 jam dalam 1 hari.

\section{Variabel-Variabel yang Diukur}

1. Lebar trotoar lurus (segmen) khusus pejalan kaki

2. Panjang trotoar lurus pejalan kaki

3. Waktu rata-rata yang dibutuhkan oleh pejalan kaki melewati segmen selasar lurus

4. Jumlah rata-rata pejalan kaki yang terdapat pada area selasar lurus pejalan kaki

5. Jumlah pejalan kaki yang melewati trotoar lurus pejalan kaki selama selang waktu (menit), kelompok pejalan kaki terdiri dari:
a. Kelompok usia dewasa
b. Kelompok usia anak
c. Kelompok usia remaja
d. Kelompok menggandeng anak
e. Kelompok pembawa barang
f. Kelompok pembawa ransel 


\section{Prosedur Pengelolaan Data}

Dari hasil pengamatan di lapangan yang direkam dengan menggunakan kamera video tersebut diharapkan dapat diperoleh data yang lengkap, karena pengamatan dapat dilakukan secara berulang-ulang sehingga informasi yang dapat diperoleh secara detail dan rinci secara aktual.

Tabel 1 Daftar Dimensi dan Luas Rata-rata Proyeksi Horizontal Pejalan Kaki

\begin{tabular}{|c|c|c|c|c|c|}
\hline \multirow{3}{*}{ No. } & \multirow{3}{*}{$\begin{array}{c}\text { Klasifikasi } \\
\text { Pejalan Kaki }\end{array}$} & \multicolumn{3}{|c|}{ DIMENSI TUBUH (RATA-RATA) } & \multirow{3}{*}{$\begin{array}{c}\text { Koefisien } \\
\text { Satuan Orang } \\
\text { Dewasa (SOD) }\end{array}$} \\
\hline & & \multicolumn{2}{|c|}{ Tebal (T) Lebar (L) } & \multirow{2}{*}{$\begin{array}{l}\text { Luas Proyeksi } \\
\text { Horizontal }\left(\mathrm{m}^{2}\right)\end{array}$} & \\
\hline & & (m) & $(\mathbf{m})$ & & \\
\hline 1 & Dewasa & 0,32 & 0,49 & 0,12 & 1 \\
\hline 2 & Remaja & 0,26 & 0,43 & 0,09 & 0,75 \\
\hline 3 & Anak & 0,16 & 0,28 & 0,04 & 0,33 \\
\hline 4 & Menggandeng Anak & 0,39 & 0,8 & 0,24 & 2,08 \\
\hline 5 & Membawa ransel & 0,59 & 0,43 & 0,21 & 1,75 \\
\hline 6 & Membawa barang & 0,96 & 0,59 & 0,445 & 3,71 \\
\hline
\end{tabular}

Data: Hasil Perhitungan dari Pengukuran di Lapangan (2019)

Analisa hubungan kecepatan-kerapatan-arus-ruang pejalan kaki di selasar lurus pejalan kaki di Pasar Antasari secara umum menggunakan prinsip dasar yang sama seperti analisa untuk kendaraan. Untuk menentukan Lebar Efektif dengan dasar tingkat pelayanan atau Level of Service (LOS) berdasarkan dari konsep yang direkomendasikan oleh Highway Capacity Manual (HCM 1994) dari Amerika. Dan perhitungan yang dilakukan dengan menggunakan rumus pada tinjauan pustaka diatas adalah sebagai berikut:

\section{Perhitungan Total Waktu-Ruang}

Total waktu ruang yang tersedia yang diperlukan untuk pejalan kaki untuk berjalan di selasar. Sebelum menentukan total waktu ruang terlebih dahulu menghitung luas efektif (A) dengan Rumus (1) dan hasil perhitungan dapat dilihat pada Tabel 1 sampai dengan Tabel 2 kolom 9) arah "A" kolom (16) arah "B". Dan setelah perhitungan luas efektif dapat diketahui, akan digunakan untuk menghitung total waktu ruang (TS) untuk lajur lurus khusus pejalan kaki menggunakan Rumus (2) dan hasil perhitungan dapat dilihat pada Tabel 4 dan Tabel 5 Kolom (3) dan (4).

\section{Perhitungan Waktu Berjalan Rata-rata}

Waktu yang dibutuhkan rata-rata seorang pejalan kaki menempati lokasi atau segmen lajur satu arah dihitung dengan Rumus (3). Dan sebagai hasil perhitungan waktu rata-rata pejalan kaki dalam menempati lokasi pengamatan dapat dilihat pada Tabel 4 dan Tabel 5 pada kolom (1) dan Kolom (2).

\section{Perhitungan Kecepatan Rata-rata}

Kecepatan rata-rata seorang pejalan kaki di lokasi pengamatan dihitung dengan menggunakan Rumus (4) dan sebagai hasil perhitungan dapat dilihat pada Tabel 4 dan Tabel 5 dan kolom (7) dan (8). 


\section{Perhitungan Waktu Total Menempati Selasar}

Waktu total pejalan kaki menempati di lokasi pengamatan dapat dihitung dengan menggunakan Rumus (5) dan sebagai perhitungan dapat dilihat pada Tabel 4 dan Tabel 5. Kolom (9) dan (10).

\section{Perhitungan Ruang Sirkulasi Rata-rata Pejalan Kaki}

Kecepatan rata-rata yang disediakan untuk setiap pejalan kaki dapat dihitung dengan menggunakan Rumus (6). Sedangkan hasil perhitungan dapat dilihat pada Tabel 4 dan Tabel 5, kolom (11) dan (12).

\section{Lebar Efektif}

Sebagai dasar dalam menganalisa Lebar Efektif dengan dasar Tingkat Pelayanan atau Level Of Service (LOS) adalah menggunakan konsep dari Tingkat Pelayanan pejalan kaki yang direkomendasikan oleh Highway Capacity Manual atau HCM (1994).

Asumsi: $\quad \mathrm{M}=\mathrm{M}=\frac{r \times D}{4}$

$$
\mathrm{D}=\frac{r \times M}{\pi} \Leftrightarrow \frac{4 \times 3,0625 \mathrm{~m}^{2} / \text { ped }}{22,7} \Leftrightarrow 0,54 \mathrm{~m} / \mathrm{ped}
$$

Untuk 2 (dua) orang pejalan kaki agar dapat berpapasan:

$\mathrm{L}=0,54 \mathrm{~m} /$ ped $\times 2$ ped $=1,08 \mathrm{~m}$

$\mathrm{L}=$ Lebar efektif selasar

Dalam HCM (1994:13-8,9), memberikan gambaran tentang Lebar Efektif Selasar Pejalan Kaki berdasarkan Tingkat Pelayanan Pejalan Kaki antara lain dapat dilihat pada Tabel 6. Diambil interval Lebar Efektif pada level C sebagai standar perhitungan untuk menentukan Lebar Efektif Selasar Pejalan Kaki, yaitu 1.26m $0,78 \mathrm{~m}$.

Tabel 2 Survey Lapangan pada Hari Selasa, Tanggal 03 Juni 2019

\begin{tabular}{|c|c|c|c|c|c|c|c|c|c|c|c|c|c|c|c|}
\hline \multirow{3}{*}{\multicolumn{2}{|c|}{\begin{tabular}{|c|c|} 
No & \\
unit & Waktu \\
menitpencatatan \\
ke-
\end{tabular}}} & \multicolumn{6}{|c|}{ PEJALAN KAKI (A) } & \multirow{3}{*}{$\begin{array}{l}\text { Luas } \\
\text { efektif } \\
\left(\mathrm{m}^{2}\right)\end{array}$} & \multicolumn{6}{|c|}{ PEJALAN KAKI (B) } & \multirow{3}{*}{\begin{tabular}{|} 
Luas \\
Efektif \\
$\left(\mathrm{m}^{2}\right)$
\end{tabular}} \\
\hline & & \multicolumn{3}{|c|}{ WAKTU (dtk) } & \multirow{2}{*}{$\begin{array}{l}\text { JLH } \\
\text { (ped) }\end{array}$} & \multirow{2}{*}{$\begin{array}{c}\text { Kecepatan } \\
(\mathrm{m} / \text { menit })\end{array}$} & \multirow{2}{*}{$\begin{array}{l}\text { Arus } \\
\text { (ped) }\end{array}$} & & \multicolumn{3}{|c|}{ KTU(dtk) } & \multirow{2}{*}{$\begin{array}{l}\text { JLH } \\
\text { (ped) }\end{array}$} & \multirow{2}{*}{$\begin{array}{l}\text { Kecepatan } \\
\text { (m/menit) }\end{array}$} & \multirow{2}{*}{$\begin{array}{l}\text { Arus } \\
\text { (ped) }\end{array}$} & \\
\hline & & MSK & KLR & Selang & & & & & MSK & KLR & Selang & & & & \\
\hline 1 & 2 & 3 & 4 & 5 & 6 & & 8 & 9 & 10 & 11 & 12 & 13 & 14 & 15 & 16 \\
\hline \multirow[t]{2}{*}{1} & 11.30 .00 & start & start & start & start & start & start & start & start & start & start & start & start & start & start \\
\hline & 11.30 .00 & 30 & 0 & 0 & 0 & 0 & 0 & 10.04 & 30 & 42 & 12 & 7 & 40 & 3 & 9.92 \\
\hline \multirow[t]{2}{*}{2} & 11.31 .00 & 0 & 12 & 12 & 8 & 40 & 1 & 10.04 & 0 & 13 & 14 & 7 & 34.28 & 4 & 9.8 \\
\hline & 11.31 .30 & 30 & 38 & 8 & 5 & 60 & 1 & 10.04 & 30 & 45 & 15 & 6 & 32 & 1 & 9.50 \\
\hline
\end{tabular}

Tabel 3 Survey Lapangan pada Hari Rabu, Tanggal 26 Juni 2019 untuk Arus Normal pada Pukul 11.30 - 12.00

\begin{tabular}{|c|c|c|c|c|c|c|c|c|c|c|c|c|c|c|c|}
\hline \multirow{3}{*}{$\begin{array}{c}\text { No } \\
\text { unit } \\
\text { menit } \\
\text { ke- }\end{array}$} & \multirow{3}{*}{$\begin{array}{c}\text { Waktu } \\
\text { pencatatan }\end{array}$} & \multicolumn{6}{|c|}{ PEJALAN KAKI (A } & \multirow{3}{*}{$\begin{array}{c}\text { Luas } \\
\text { efektif } \\
\left(\mathrm{m}^{2}\right)\end{array}$} & \multicolumn{6}{|c|}{ PEJALAN KAKI (B) } & \multirow{3}{*}{$\begin{array}{l}\text { Luas } \\
\text { efektif } \\
\left(\mathrm{m}^{2}\right)\end{array}$} \\
\hline & & \multicolumn{3}{|c|}{ WAKTU (dtk) } & \multirow{2}{*}{$\begin{array}{l}\text { JLH } \\
\text { (ped) }\end{array}$} & \multirow{2}{*}{$\begin{array}{l}\text { Kecepatan } \\
\text { (m/menit) }\end{array}$} & \multirow{2}{*}{$\begin{array}{l}\text { Arus } \\
\text { (ped) }\end{array}$} & & \multicolumn{3}{|c|}{ WAKTU (dtk) } & \multirow{2}{*}{$\begin{array}{l}\text { JLH } \\
\text { (ped) }\end{array}$} & \multirow{2}{*}{$\begin{array}{l}\text { Kecepatan } \\
\text { (m/menit) }\end{array}$} & \multirow{2}{*}{$\begin{array}{l}\text { Arus } \\
(\text { ped })\end{array}$} & \\
\hline & & MSK & KLR & Selang & & & & & MSK & KLR & Selang & & & & \\
\hline 1 & 2 & 3 & 4 & 5 & 6 & 7 & 8 & 9 & 10 & 11 & 12 & 13 & 14 & 15 & 16 \\
\hline \multirow[t]{2}{*}{1} & 11.30 .00 & start & start & start & start & start & start & start & start & start & start & start & start & start & start \\
\hline & 11.30 .00 & 30 & 39 & 9 & 5 & 53.33 & 5 & 10.4 & 30 & 0 & 0 & 0 & 0 & 0 & 10.24 \\
\hline \multirow[t]{2}{*}{2} & 11.31 .00 & 0 & 0 & 0 & 0 & & 3 & 10.4 & 0 & 0 & 0 & 0 & 0 & 3 & 10.24 \\
\hline & 11.31 .30 & 30 & 0 & & 0 & & 1 & 10.4 & 30 & 0 & 0 & 0 & 0 & 6 & 10.24 \\
\hline
\end{tabular}




\section{HASIL DAN PEMBAHASAN}

\section{Hasil Kompilasi Data Kecepatan dan Kerapatan}

Pada Tabel 4 untuk hasil survey atau pengamatan di selasar lurus pejalan kaki kondisi arus puncak dan Tabel 5 untuk pengamatan pada selasar lurus untuk kondisi normal.

\section{Hasil Kompilasi Data Karakteristik Pejalan Kaki}

Pada Tabel 1 sampai dengan Tabel 5, maupun dari arah sebaliknya, sebelumnya harus memperoleh data karakteristik dari pejalan kaki sesuai dengan definisi dari klasifikasi.

\section{Luasan Proyeksi Horizontal Pejalan Kaki dengan Satuan Pejalan Kaki}

Seperti halnya juga dalam lalu lintas kendaraan satuan pejalan kaki diambil sebagai standar adalah luasan (A) badan orang dewasa.

\section{Perhitungan Kerapatan Rata-rata Pejalan Kaki}

Kecepatan rata-rata yang disediakan untuk pejalan kaki dihitung dengan menggunakan Rumus (7), dan sebagai hasil perhitungan dapat dilihat pada Tabel 2 dan Tabel 4 Kolom (13) dan (14)

\section{Menentukan Lebar Efektif}

Perhitungan Lebar Efektif dari pejalan kaki yang melalui selasar lurus didasarkan pada Highway Capacity Manual HCM (1994)

1. Kondisi Waktu Puncak

$$
\begin{aligned}
& \mathrm{M} \text { (ruang) }=1,69 \mathrm{~m}^{2} / \text { ped } \rightarrow 18,46 \mathrm{ft}^{2} / \text { ped } \\
& \text { Asumsi: } \mathrm{M}=\text { Luas lingkaran } \Leftrightarrow \mathrm{M}=\frac{r \times D}{4} \\
& \mathrm{D}=\frac{r \times M}{\pi} \Leftrightarrow \frac{r \times 1,69 \mathrm{~m}^{2} / \text { ped }}{22,7} \Leftrightarrow 0,297 \mathrm{~m} / \text { ped }
\end{aligned}
$$

Untuk 2 (dua) orang pejalan kaki agar dapat berpapasan:

$\mathrm{L}=0,297 \mathrm{~m} /$ ped $\times 2$ ped $=0,594 \mathrm{~m}$

$\mathrm{L}=$ Lebar efektif selasar

2. Kondisi Waktu Normal

$\mathrm{M}$ (ruang) = 3,0625 $\mathrm{m}^{2} /$ ped

Asumsi: $\mathrm{M}=$ Luas lingkaran $\Leftrightarrow \mathrm{M}=\frac{r \times D}{4}$

$\mathrm{D}=\frac{r \times M}{\pi} \Leftrightarrow \frac{r \times 1,69 \mathrm{~m}^{2} / \text { ped }}{22,7} \Leftrightarrow 0,297 \mathrm{~m} /$ ped

Untuk 2 (dua) orang pejalan kaki agar dapat berpapasan

$\mathrm{L}=0,54 \mathrm{~m} /$ ped $\times 2$ ped $\sim 1,08 \mathrm{~m}$

$\mathrm{L}=$ Lebar efektif selasar. 
JURNAL KACAPURI

JURNAL KEILMUAN TEKNIK SIPIL

Volume 3 Nomor 2 Edisi Desember 2020

Tabel 4 Hasil Perhitungan Arus Puncak

\begin{tabular}{|c|c|c|c|c|c|c|c|c|c|c|c|c|c|c|c|}
\hline \multirow{2}{*}{$\begin{array}{l}\text { tw A } \\
\text { (sees) }\end{array}$} & \multirow{2}{*}{$\begin{array}{l}\text { tw B } \\
\text { (sees) }\end{array}$} & \multicolumn{2}{|c|}{$\begin{array}{c}\text { Ts } \\
\left(\mathrm{m}^{2}-\mathrm{mnt}\right)\end{array}$} & \multirow{2}{*}{$\begin{array}{c}\text { VA } \\
\text { (ped/mnt) }\end{array}$} & \multirow{2}{*}{$\begin{array}{c}\mathrm{VB} \\
\text { (ped/mnt) }\end{array}$} & \multicolumn{2}{|c|}{$\begin{array}{c}\text { Kecepatan } \\
(\mathrm{m} / \mathrm{mnt})\end{array}$} & \multicolumn{2}{|c|}{$\begin{array}{c}\text { TW } \\
\text { (ped-mnt) }\end{array}$} & \multicolumn{2}{|c|}{$\begin{array}{l}\text { Ruang (M) } \\
\text { (m²-ped) }\end{array}$} & \multicolumn{2}{|c|}{$\begin{array}{c}\begin{array}{c}\text { Kerapatan } \\
\left(\text { ped- } m^{2}\right)\end{array} \\
\end{array}$} & \multicolumn{2}{|c|}{$\begin{array}{c}\text { Arus } \\
\text { (ped } / \mathrm{mnt} / \mathrm{m}\end{array}$} \\
\hline & & $\begin{array}{l}\text { arth } \\
\text { A }\end{array}$ & $\begin{array}{c}\text { arth } \\
\text { B }\end{array}$ & & & $\begin{array}{c}\text { arth } \\
\text { A }\end{array}$ & $\begin{array}{c}\text { arth } \\
\text { B }\end{array}$ & $\begin{array}{c}\text { arth } \\
\text { A }\end{array}$ & $\begin{array}{c}\text { arth } \\
\text { B }\end{array}$ & $\begin{array}{c}\text { arth } \\
\text { A }\end{array}$ & $\begin{array}{c}\text { arth } \\
\text { B }\end{array}$ & $\begin{array}{c}\text { arth } \\
\text { A }\end{array}$ & $\begin{array}{c}\text { arth } \\
\text { B }\end{array}$ & $\begin{array}{c}\text { arth } \\
\text { A }\end{array}$ & $\begin{array}{c}\text { arth } \\
\text { B }\end{array}$ \\
\hline 12,00 & 13,00 & 10,04 & 9,86 & 8,00 & 14,00 & 20,00 & 37,14 & 1,60 & 3,03 & 6,28 & 3,94 & 0,16 & 0,25 & 7,69 & 4,61 \\
\hline 12,80 & 15,51 & 10,04 & 9,80 & 16,00 & 14,00 & 46.00 & 31,00 & 2,90 & 3,63 & 3,46 & 3,77 & 0,28 & $0^{\wedge} 26$ & 6,15 & 10,76 \\
\hline 16,00 & 16,00 & 9,92 & 9.80 & 18,00 & 12.00 & 30,00 & 29,36 & 3,83 & 3,20 & 2.59 & 3,74 & 0.38 & 0.27 & 1076 & 923 \\
\hline
\end{tabular}

Tabel 5 Hasil Perhitungan Arus Normal

\begin{tabular}{|c|c|c|c|c|c|c|c|c|c|c|c|c|c|c|c|}
\hline \multirow{2}{*}{$\begin{array}{l}\text { tw A } \\
\text { (sees) }\end{array}$} & \multirow{2}{*}{$\begin{array}{l}\text { tw B } \\
\text { (sees) }\end{array}$} & \multicolumn{2}{|c|}{$\begin{array}{c}\text { Ts } \\
\left(\mathrm{m}^{2}-\mathrm{mnt}\right)\end{array}$} & \multirow{2}{*}{$\begin{array}{c}\mathrm{VA} \\
(\mathrm{ped} / \mathrm{mnt})\end{array}$} & \multirow{2}{*}{$\begin{array}{c}\mathrm{VB} \\
\text { (ped/mnt) }\end{array}$} & \multicolumn{2}{|c|}{$\begin{array}{c}\text { Kecepatan } \\
(\mathrm{m} / \mathrm{mnt})\end{array}$} & \multicolumn{2}{|c|}{\begin{tabular}{|c|} 
TW \\
(ped-mnt)
\end{tabular}} & \multicolumn{2}{|c|}{$\begin{array}{c}\text { Ruang (M) } \\
\left(\mathrm{m}^{2} \text {-ped) }\right.\end{array}$} & \multicolumn{2}{|c|}{$\begin{array}{l}\text { Kerapatan } \\
(\text { ped-m²) }\end{array}$} & \multicolumn{2}{|c|}{$\begin{array}{c}\text { Arus } \\
\text { (ped } / \mathrm{mnt} / \mathrm{m}\end{array}$} \\
\hline & & $\begin{array}{c}\text { arth } \\
\text { A }\end{array}$ & $\begin{array}{c}\text { arth } \\
\text { B }\end{array}$ & & & $\begin{array}{c}\text { arth } \\
\text { A }\end{array}$ & $\begin{array}{c}\text { arth } \\
\text { B }\end{array}$ & $\begin{array}{c}\text { arth } \\
\text { A }\end{array}$ & $\begin{array}{c}\text { arth } \\
\text { B }\end{array}$ & $\begin{array}{c}\text { arth } \\
\text { A }\end{array}$ & $\begin{array}{c}\text { arth } \\
\text { B }\end{array}$ & $\begin{array}{c}\text { arth } \\
\text { A }\end{array}$ & $\begin{array}{c}\text { arth } \\
\text { B }\end{array}$ & $\begin{array}{c}\text { arth } \\
\text { A }\end{array}$ & $\begin{array}{c}\text { arth } \\
\text { B }\end{array}$ \\
\hline 9,00 & 0,00 & 10,40 & 10,24 & 5,00 & 0,00 & 26,67 & 0,00 & 0,75 & 0,00 & 13,87 & $\ldots$ & 0,07 & $\ldots$ & 12,30 & 4,61 \\
\hline 0,00 & 00 & 10,28 & 10,24 & 00 & 0,00 & 0,00 & 0,00 & 0,00 & 0,00 & & & & & 7,69 & 10,76 \\
\hline 9,00 & 12,00 & 10,16 & 10,24 & 5,00 & 8,00 & 26,67 & 20,00 & 0,75 & 1,60 & 13,55 & 6,40 & 0,07 & 0,16 & 10,76 & 1,53 \\
\hline
\end{tabular}

Tabel 6 Hubungan Tingkat Pelayanan, Ruang dan Lebar Efektif

\begin{tabular}{|c|c|c|}
\hline Tingkat Pelayanan & Ruangan $\left(\mathbf{m}^{\mathbf{2}} / \mathbf{p . k a k i}\right)$ & Lebar Efektif $(\mathbf{m})$ \\
\hline A & $>11,94$ & $>4,2$ \\
\hline B & $11,85-3,67$ & $4,17-1,3$ \\
\hline C & $3,58-2,20$ & $1,26-0,78$ \\
\hline D & $2,11-1,38$ & $0,74-0,49$ \\
\hline E & $1,28-0,55$ & $0,45-0,19$ \\
\hline F & $<0,46$ & $<0,16$ \\
\hline
\end{tabular}

\section{Kesimpulan}

\section{PENUTUP}

Berdasarkan dari uraian dan hasil yang didapat maka berikut ini dapat dibuat suatu kesimpulan antara lain sebagai berikut:

Lebar Efektif Selasar Pejalan Kaki pada waktu puncak dan waktu normal yang didasarkan pada konsep dari HCM (1994) dan konversi satuan $\mathrm{m}^{2} / \mathrm{ped}$

1. Kondisi Waktu Puncak

$$
\begin{array}{ll}
\mathrm{M} \text { (Ruang) } & =1,69 \mathrm{~m}^{2} / \mathrm{ped} \\
\text { Lebar Efektif Selasar } & =0,594 \mathrm{~m}
\end{array}
$$

2. Kondisi Waktu Normal

$\begin{array}{ll}\mathrm{M} \text { (Ruang) } & =3,0625 \mathrm{~m}^{2} / \mathrm{ped} \\ \text { Lebar Efektif Selasar } & =1,08 \mathrm{~m}\end{array}$

Saran

Untuk dapat lebih mendalam dan lebih lengkap lagi tentang khasanah keilmuan dan pengetahuan tentang pejalan kaki (pedestrian) dalam kaitannya dengan sistem transportasi

di Indonesia, maka perlu dilakukan penelitian atau kajian lebih lanjut mengenai:

1. Lebar Efektif Selasar yang didasarkan dari data-data kuantitatif atau segi sosial yang berupa rasa aman, nyaman (copet, pencuri, jambret dan lain-lain), keselamatan orang/barang akibat benturan dan lain sebagainya, karena Lebar 
Efektif dari konsep HCM (1994) dari Amerika yang hanya didasarkan pada data kuantitatif.

2. Penelitian serupa di tempat-tempat lain seperti pada selasar gedung perkantoran berlantai banyak, supermarket, rumah sakit, theater, stasiun, pelabuhan dan tempat- tempat yang lainnya yang nanti akan kita ketahui karakteristik para pejalan kaki di tempat tertentu.

3. Perlu pelebaran selasar untuk meningkatkan kinerja fasilitas yang telah ada berupa mengalihkan Pedagang Kaki Lima (PKL) ke tempat khusus.

\section{DAFTAR PUSTAKA}

1. Pushkarev, B. \& M.J. Zupan. 1975. Urban Spaces for Pedestrian, The MIT Press, Cambridge, Mass

2. Transportation Research Board. 1994. Highway Capacity Manual, Special Report 209, Washington DC.

3. Undang-Undang No. 14. 1992. Lalu Lintas dan Angkutan Jalan, Arkola, Surabaya.

4. Wapolke, R.E. \& R.H. Myers. 1995. Ilmu Peluang dan Statistika untuk Insinyur dan Ilmuwan, Edisi ke-4, Institut Teknologi Bandung, Bandung. 